\title{
Form, Topics, and Harmonic Schemata in Beethoven's String Quartet Op. 18 No. 4/I, in C Minor
}

\author{
Forma, Tópicos e Esquemas Harmônicos no primeiro movimento \\ do Quarteto de Cordas Op. $18 n^{\circ}$ 4, em Dó menor
}

\author{
Mítia D'Acol \\ Indiana University \\ mganade@iu.edu
}

\begin{abstract}
Bridging the gap between different cultural contexts such as the one between a modern listener and an $18^{\text {th }}$-century listener has been a constant interest of contemporary musicologists and theorists - especially those dedicated to the study of galant schemata, topic theory, and formal functions. Although these theories are usually used separately when analysing a musical discourse, recent studies have been leaning on the benefits of entwining them in order to build a richer understanding of a piece of music. Therefore, the aim of this paper is to present an analysis of the first movement of Beethoven's String Quartet in C Minor, Op. 18 No. 4 where all of the aforementioned analytical techniques are used to better expose different levels of interpretation that emerge from overlapping topic theory, formal functions, and galant schemata analyses.
\end{abstract}

Keywords: Beethoven; topic theory; galant schemata; classical form

Resumo: Diminuir a distância entre diferentes contextos culturais como o que existe entre um ouvinte moderno e outro oitocentista tem sido um interesse constante de musicólogos e teóricos contemporâneos - especialmente aqueles dedicados ao estudo de esquemas galantes, teoria das tópicas e funções formais. Embora estas teorias normalmente sejam utilizadas separadamente em análises do discurso musical de uma peça, estudos recentes vêm demonstrando os benefícios do entrelaçamento destas teorias de forma a construir um entendimento mais rico de uma música. Portanto, o objetivo deste artigo é apresentar uma análise do primeiro movimento do Quarteto de Cordas em Dó Menor, Op. 18 nº 4 de Beethoven, em que todas as técnicas analíticas acima mencionadas serão usadas para melhor expor diferentes níveis de interpretaçã o que emergem da sobreposição das análises tópicas, esquemáticas e das funções formais.

Palavras-chave: Beethoven; teoria das tópicas; esquemas galantes; formas clássicas 


\section{1 - Introduction}

The string quartet and other genres are not construed only upon a certain set of shared characteristics, they are also deeply tied to conventionalized meanings and structures - therefore, culture and context play a central role in the understanding of such genres (Kallberg 1996, p. 5). For Cobley (2008, p. 14-33), context in music communication are all the shared referential functions between composers and listeners but not only as an external universe: indeed as a part of the music per se. In order to access context, one must look to this music and draw from it the possible references imbued in its discourse.

However evident some of the aforementioned facts can be to a modern experienced listener, the reception of classical music in modern times is sometimes distorted by the listening Romantic aesthetics. Scholars who studied the use of topics and harmonic schemata in the repertoire often bring this distortion to our attention, and offer theories that attempt to bridge the gap between our different cultural contexts ${ }^{1}$. Therefore, to distance ourselves from a purely phraseological, harmonic, and structural analysis, we will use those theories to discuss the highly conventionalized signs and gestures present in late eighteenth-century music.

In this paper, we will analyze the first movement of Beethoven's String Quartet in C Minor, Opus 18, No. 4, by means of scrutinizing the discourse created by listening and interpreting some of the topics suggested by the music. We will also discuss the relationship between these topics, considering Hatten's (2014, p. 514-539) four axes of topical relations (compatibility, dominance, creativity, and productivity) and the tropological potential of topics inside the quartet. We will consider the formal analysis of classic sonata form and its structural organization of contrast perception; however, drawing from Allanbrook's (2014, p. 118) comparison between long and short-term contrast, our main goal will be to assess the idea that contrast in this particular form "emerges not from long-term structural memory but from the immediate aural comparison of things side-by-side."

\section{2 - Overall Form}

The first movement is undoubtedly written in sonata form. For this account, I am using Caplin's (1998) theory of sonata form, developed across

\footnotetext{
1 For a comprehensive account of such theories, see Danuta Mirka, "Introduction", in Communication in Eighteenth-Century Music, Danuta Mirka and Kofi Agawu (eds.). Cambridge: Cambridge University Press, 2008, p. 2-4.
} 
eleven formal sections punctuated mostly by strong cadences; some blending in particular will be discussed later on the paper. Although very prototypical at a first glance, the overall form has raised some discussion regarding specific sections. Hatten (1994, p. 122) describes the first theme as an experiment that Beethoven tried in the first attempt of a six quartets set regarding the markedness of unusual phrase constructions (what seems to be a Satz, with its prototypical structure of $[2+2]+[\{1+1\}+2]$ measures, is expanded with four more measures). Hepokosky and Darcy (2006, p. 45) describe the two-part transition as a typical declined medial caesura inside a trimodular block. Caplin (1998 p. 264) quotes the quartet as offering an example of development where the pre-core starts with a restatement of the first theme. Table 1 provides a summary of the main keys, modulations, formal functions, and topics that are found in the first movement of Beethoven's Op. 18 № 4 .

The strategy of our analysis is to follow Beethoven's discursive thread, unfolding the use of topics and their agency during the listening experience of the movement. I believe, that the some of the topics used in Beethoven's discourse for this piece (brilliant style, learned style and tempesta $a^{2}$ ) are particularly those described by Caplin (2005, p. 113-124) as having a possible or likely relation to formal sections of the sonata. The remaining topics (bourrée, singing style, ombra and buffa style) are treated as non-analogous to specific parts of sonata form; however, the syntactical choice of some of these topics in this movement is apparently related to or has a strong meaningful function in specific sections of this piece, as discussed below.

\begin{tabular}{|c|c|c|c|l|}
\cline { 2 - 5 } \multicolumn{1}{c|}{} & $\begin{array}{c}\text { Formal } \\
\text { Section }\end{array}$ & Bar & Key & \multicolumn{1}{|c|}{ Topic } \\
\hline \multirow{1}{*}{ Exposition } & Main Theme & $1-13$ & $\mathrm{Cm}$ & $\begin{array}{l}\text { Tempesta } \\
\text { Singing Style/ Bourrée }\end{array}$ \\
\cline { 2 - 5 } & $\begin{array}{c}\text { Transition } \\
\text { (two-part) }\end{array}$ & $14-33$ & $\begin{array}{l}\mathrm{Cm} \triangleright \mathrm{Ab} \\
\triangleright \mathrm{Fm}\end{array}$ & $\begin{array}{l}\text { Tempesta } \\
\text { Buffa style (26-33) }\end{array}$ \\
\cline { 2 - 5 } & $\begin{array}{c}\text { Subordinate } \\
\text { Theme }\end{array}$ & $34-70$ & $\mathrm{~Eb}$ & $\begin{array}{l}\text { Singing Style with buffa style } \\
\text { commentaries (mm. 35 and 37) } \\
\text { Brilliant Style (49-52) } \\
\text { Bourrée or peasant heavy-footed } \\
\text { dance (54-60) } \\
\text { Brilliant Style (66-68) }\end{array}$ \\
\cline { 2 - 5 } & $\begin{array}{c}\text { Closing } \\
\text { Section }\end{array}$ & $70-77$ & $\mathrm{~Eb} \triangleright \mathrm{Cm}$ & Ombra \\
\hline
\end{tabular}

2 The term tempesta, proposed by McClelland (2014, p. 279-300) as a substitute for Sturm und Drang, was not published at the time of Caplin's essay. I understand that tempesta is a more appropriated concept and should be used here instead of Sturm und Drang. 


\begin{tabular}{|c|c|c|c|c|}
\hline & $\begin{array}{l}\text { Formal } \\
\text { Section }\end{array}$ & Bar & Key & Topic \\
\hline \multirow{4}{*}{ Development } & \multirow{3}{*}{ Pre-core } & $78-90$ & $\mathrm{Gm}$ & Tempesta \\
\hline & & 90-111 & $\begin{array}{l}\mathrm{Gm} \triangleright \mathrm{Cm} \\
\triangleright \mathrm{Fm}(\mathrm{V})\end{array}$ & $\begin{array}{l}\text { Tempesta } \\
\text { Learned Style }\end{array}$ \\
\hline & & $112-127$ & $\mathrm{~F} \succ \mathrm{Fm}$ & Singing Style \\
\hline & $\begin{array}{l}\text { Standing on } \\
\text { the Dominant }\end{array}$ & 128-135 & $\mathrm{Cm}(\mathrm{V})$ & Ombra \\
\hline \multirow{4}{*}{ Recapitulation } & Main Theme & $136-148$ & $\mathrm{Cm}$ & $\begin{array}{l}\text { Tempesta } \\
\text { Singing Style/Bourrée }\end{array}$ \\
\hline & Transition & $148-157$ & $\mathrm{Cm} \gg \mathrm{Cm}$ & Tempesta \\
\hline & $\begin{array}{c}\text { Subordinate } \\
\text { Theme }\end{array}$ & 158-194 & C & $\begin{array}{l}\text { Singing Style } \\
\text { Brilliant Style (49-52) } \\
\text { Bourrée or peasant heavy-footed } \\
\text { dance (54-60) } \\
\text { Brilliant Style (66-68) }\end{array}$ \\
\hline & $\begin{array}{l}\text { Closing } \\
\text { Section }\end{array}$ & 194-201 & C & Ombra \\
\hline Coda & Coda & 202-219 & $\mathrm{Cm}$ & $\begin{array}{l}\text { Tempesta } \\
\text { Buffa Style }\end{array}$ \\
\hline
\end{tabular}

Table 1: Formal organization and topics in Beethoven's String Quartet in C minor, Op. 18, No. 4 first movement

\section{3 - Analysis}

The quartet starts with a sentence, written in tempesta style, with the prototypical thriving rhythm, dissonant harmony, and minor mode that define the topic (Example 1). Despite the dominance of the topic in the foreground - or surface- of the listening experience, we may recognize other topics hidden under the tempesta style markers. The first one that calls attention is the singing style: the melody in the first violin is a simple, singable, and beautiful one. Singable here, as Day-O'Connel (2014, p. 245) states, "does not mean [...] as in avoiding leaps, incorporating breaths, and adhering to the compass of the voice, but singable in the sense of comprehensive". Here, the compatibility and dominance relations between the two topics suggest what Hatten calls a ratio 
facilis case of tropological interpretation ${ }^{3}$. Despite their apparent opposite meanings (beautiful, natural, and simple of the singing style against the terror, frenzy, and rage of the tempesta) the use of both topics together is of easy recognition by experienced listeners and the use of tempesta in the vocal universe (such as operas) is quite common ${ }^{4}$. If we venture deeper into the musical gestures in the first measures of the music, we can see a hint of a bourrée dance topic in the melody. The hint is mainly rhythmic, an upbeat gesture present throughout the melody, the mixture of leaps and hops and the syncopated figures of mm. 5-7, 9-10, and $11^{5}$.

Therefore, the occurrence of a bourrée with singing style and tempestaelicits a ratio dificilis owed to the degree of incompatibility between the dance and the stormy tempesta topic. The dominance of tempesta is quite clear given it is the topic with most used parameters; however, the background dance rhythm creates a new emergent meaning to the topic: a lively, simple dance is transformed into a frenzy, desperate one. This emergent meaning can be initially uncertain for the listener but it will be developed by the composer to guarantee its understanding, as Hatten (2014, p. 524) describes: "The power of a creatively fresh trope is in the emergence of new meaning for the listener. But the instability, or indeterminacy, of a listener's interpretation obligates a composer to provide ongoing clues to guide that listener, both in identifying the tropological encounter and in continuously interpreting its consequences".

\footnotetext{
${ }^{3}$ Hatten (2015, p. 516) borrows Umberto Eco's concepts of ratio facilis and ratios dificilis to explain the difference between more conventional and more creative troping in music.

4 See McClelland, "Ombra and Tempesta," p. 286, and Mary Hunter, "Topics and Opera Buffa" p. 83 in The Oxford Handbook of Topic Theory, ed. Danuta Mirka (Oxford: Oxford University Press, 2014).

${ }^{5}$ The bourrée characteristics are defined by Wye J. Allanbrook in Rhythmic Gesture in Mozart: Le nozze di Figaro and Don Giovanni (Chicago: University of Chicago Press, 1983), p. 48-49, and Meredith E. Little in "The Contribution of Dance Steps to Musical Analysis and Performance: 'La Bourgogne'." Journal of the American Musicological Society, vol. 28, no. 1, Spring, 1975, p. 116.
} 


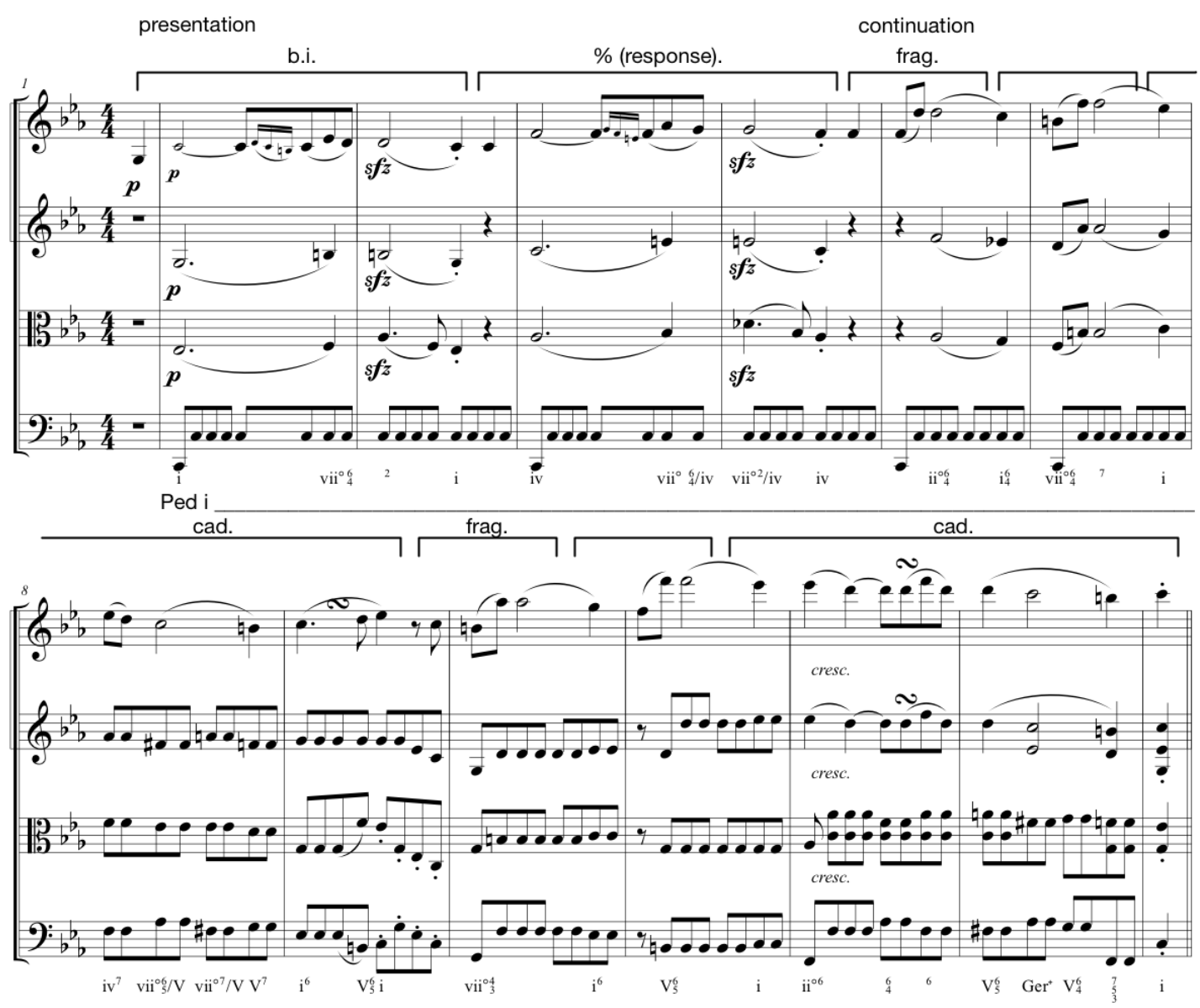

Example 1: Beethoven, String Quartet in C Minor, Op. 18 № 4/I, mm. 1-13

The end of the main theme connects with the beginning of the transition through the residual force coming from the precedent prevailing topic (tempesta) as Ratner ${ }^{6}$ describes: "the pulsating bass, the Storm and Stress manner, and the broadly scaled melody all drive the action past the normal cadential point". In other words, the topical content of the first theme drives forward the gesture of a PAC in the last measure of the first theme, connecting it directly with the beginning of the transition (mm. 12-14). After the repeated PAC gesture Beethoven stretches out the phrase for a new cadence, this time arriving on the dominant in $\mathrm{m}$. 20, where he hints the next topic which contrasts with the overall tempesta topic that dominated the foreground of musical discourse thus far (Example 2). The violin melody has some of the qualities of the buffa style: the transitional quality of the dominant pedal with slower harmonic rhythm paired

${ }_{6}^{6}$ Leonard Ratner. Classic Music: Expression, Form and Style. New York: Schirmer Books, 1985, p.43. 
with a light, theatrical articulation ensures the listener that the frenzy tempesta feeling is now far behind.

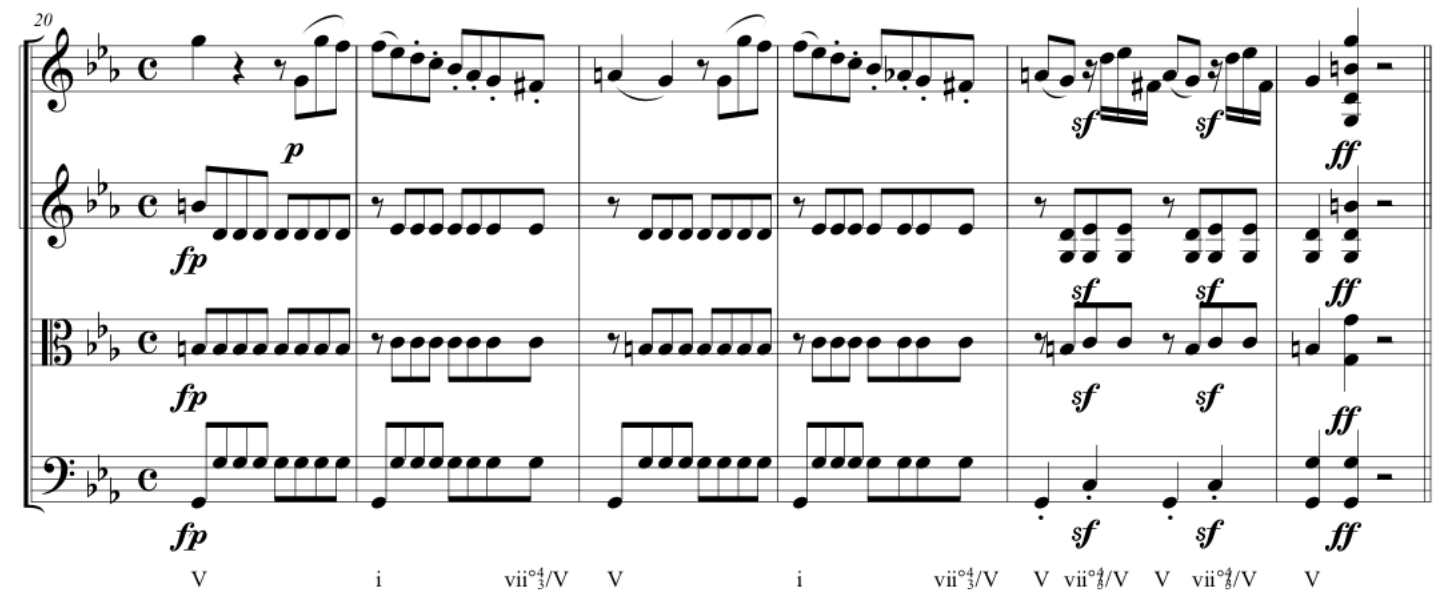

Example 2: Beethoven, String Quartet in C Minor, Op. 18 № 4/I, mm. 20-25

After the half-cadence caesura in m. 25, an eight-measure passage (Example 3) confirms this new, contrasting topic in the submediant (Ab major, mm. 26-29) and subdominant (F minor, mm. 30-33), which could be further interpreted respectively as IV and ii in the next key (Eb major). Its recognition come from various aspects: the staccato articulation in the violoncello parts, the overall simple harmony progressions (the cyclic changing between tonic and dominant sonorities), and the dialogue between the two violins that points to a translation of theatrical elements to the chamber style. Moreover, this is the first passage of the quartet that clearly presents a concatenation of galant schemata ${ }^{7}$, which are not always correlated to specific topics ${ }^{8}$, but in this case are a marker for a lighter musical language closely related to the universe of opera buffa. An experienced listener of galant music would recognize two schemata in the passage: the Fenaroli ${ }^{9}$ and Comma ${ }^{10}$.

\footnotetext{
${ }^{7}$ For more on galant schemata, see Robert O. Gjerdingen, Music in the Galant Style (New York: Oxford University Press, 2007).

8 Vasili Byros, "Topics and Harmonic Schemata: A Case from Beethoven", in The Oxford Handbook of Topic Theory, ed. Danuta Mirka, Oxford: Oxford University Press, 2014, p. 381-414.

${ }_{9}^{9}$ Gjerdingen, Music in the Galant Style, p. 225-240.

${ }^{10}$ Ibid., p. $155-158$.
} 


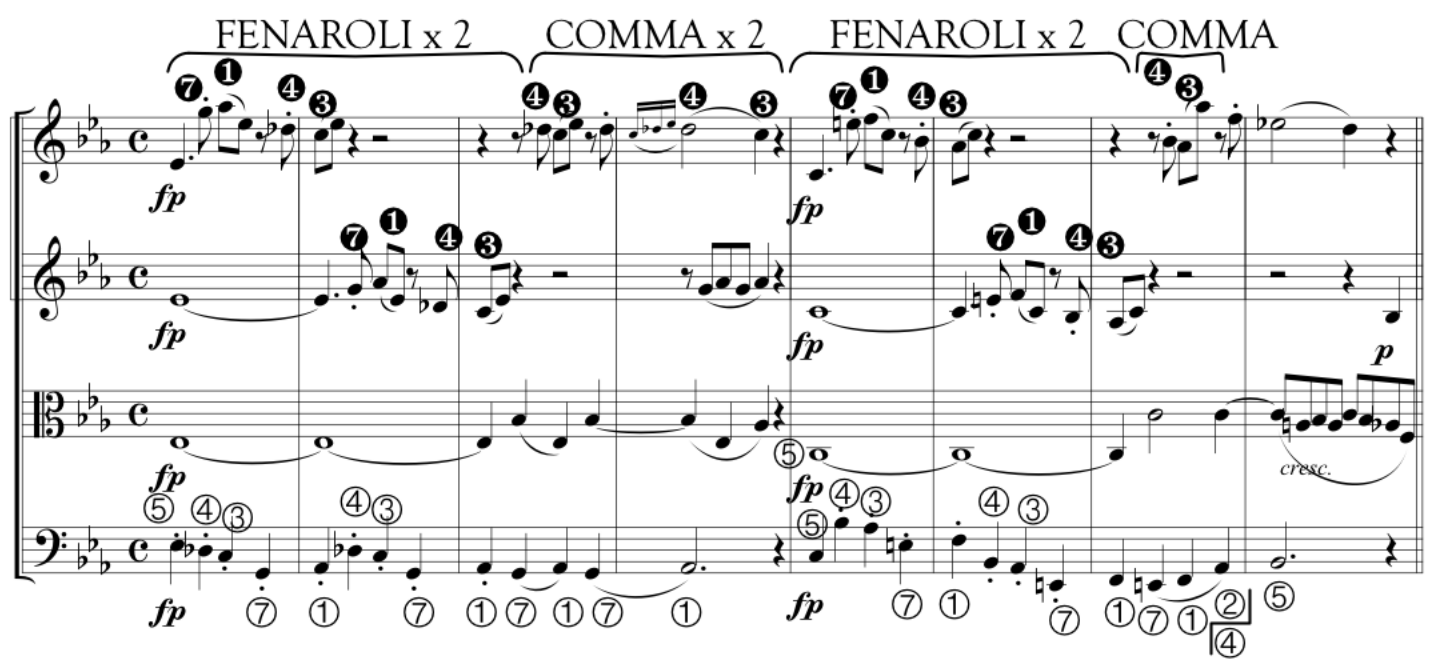

Example 3: Beethoven, String Quartet in C Minor, Op. 18 № 4/I, mm. 26-33

The contrast between the topical content of the main theme and the second part of the transition is evident: whereas the first brings a trope of tempesta, singing style and a middle-rank dance (bourrée) - thus expressing high turmoil and conflict given the degree of incompatibility between topics, the second is straight-forward in its content, a display of buffa style which, as Hunter ${ }^{11}$ states, "depends entirely on the light-footed and dialogic quality of the music, which quite viscerally evokes the sense of several characters variously running and gesturing to each other". They also contrast regarding their degree of dignity (high, middle, or low), the main theme ranked in a middle, possibly high tragic style (marked) and the second part of the transition as low comic style (unmarked) ${ }^{12}$. This contrast is not an odd placement of the known difference of character between main and subordinate themes (and not even a great stretch of locus topicus, since all these topics are present in theatrical style), but functions maybe as a comment on the prevailing discourse so far: after a dramatic display of tragical content, two characters appear and start commenting (with a comic intent) the previous event.

The buffa passage gives place to the subordinate theme group, where the singing style from the main theme is no longer overshadowed by the tempesta topic, presented in a clear texture over an arpeggiated bass (Example 4). The melody borrows from the fragmentations in the first theme ( $\mathrm{mm} .5-9)$, expanding the main theme's sequence of intervals in a diatonic, non-sequential manner. The sequence of leaps (minor sixth, minor seventh, and octave) follows the inherent characteristic of simplicity from the singing style, but after each leap we hear a

${ }^{11}$ Hunter, "Topics and Opera Buffa," p. 78.

${ }^{12}$ For more on markedness of specific styles, see Hatten, Musical Meaning in Beethoven, p. 74-82. 
residual topic from the transition: the buffa style gesture in the first violin $(\mathrm{mm}$. 35 and 37) is still commenting over the prevalent topic.

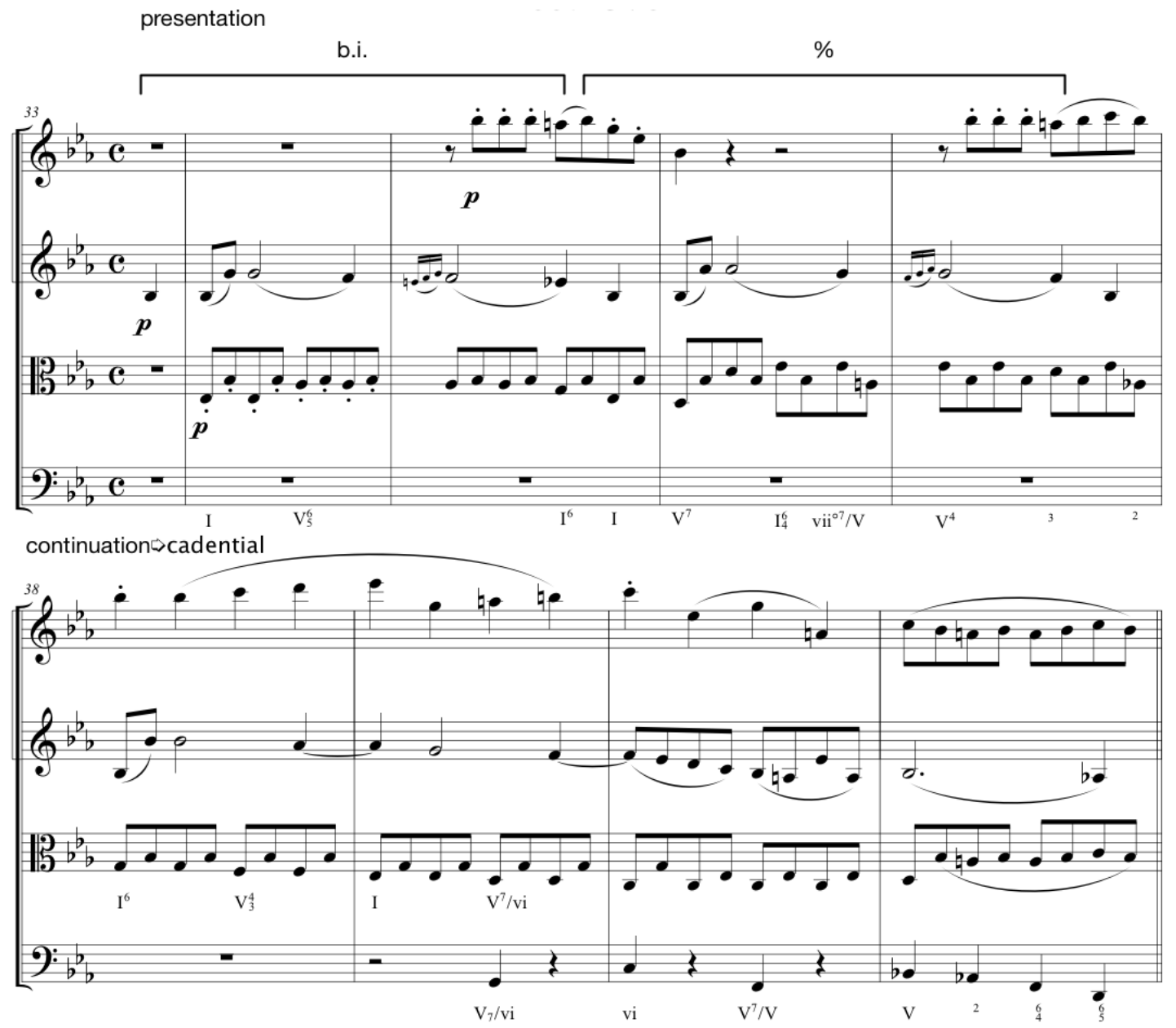

Example 4: Beethoven, String Quartet in C Minor, Op. 18 № 4/I, mm. 33-41

This gesture is lost in the repetition of the theme (mm. 42-49), where a fuller texture is introduced with violin and viola playing the melody, the second violin joining in a third below, and the bass consisting of mainly arpeggiated chords. The other topic present in the subordinate theme group is the brilliant style (Example 5a and $b$ ), with a very short apparition on the first violin. The brilliant style is quite compatible with the singing style, if we take as basis the translation of theatrical virtuoso style of singing into account. The second theme of the subordinate group (Example 6) is displayed in a simple homophonic texture, and can either be interpreted as a bourrée with metrical manipulation (due to the sforzando on the first weak beat of the measure), or probably a heavyfooted peasant dancing. Both options of interpretation here cohere with the overall relation between tragic/comic and middle/low style across the piece. 


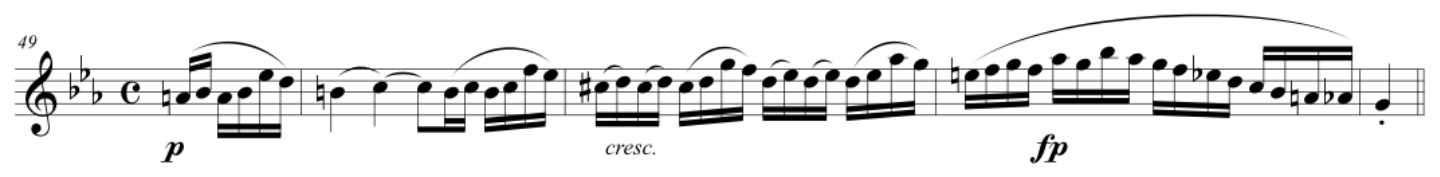

(a)

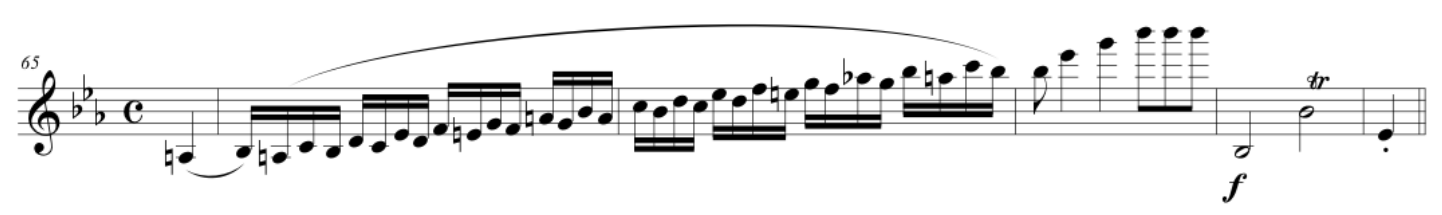

(b)

Example 5: Beethoven, String Quartet in C Minor, Op. 18 № 4/I

(a) mm. 49-53; (b) mm. 65-70

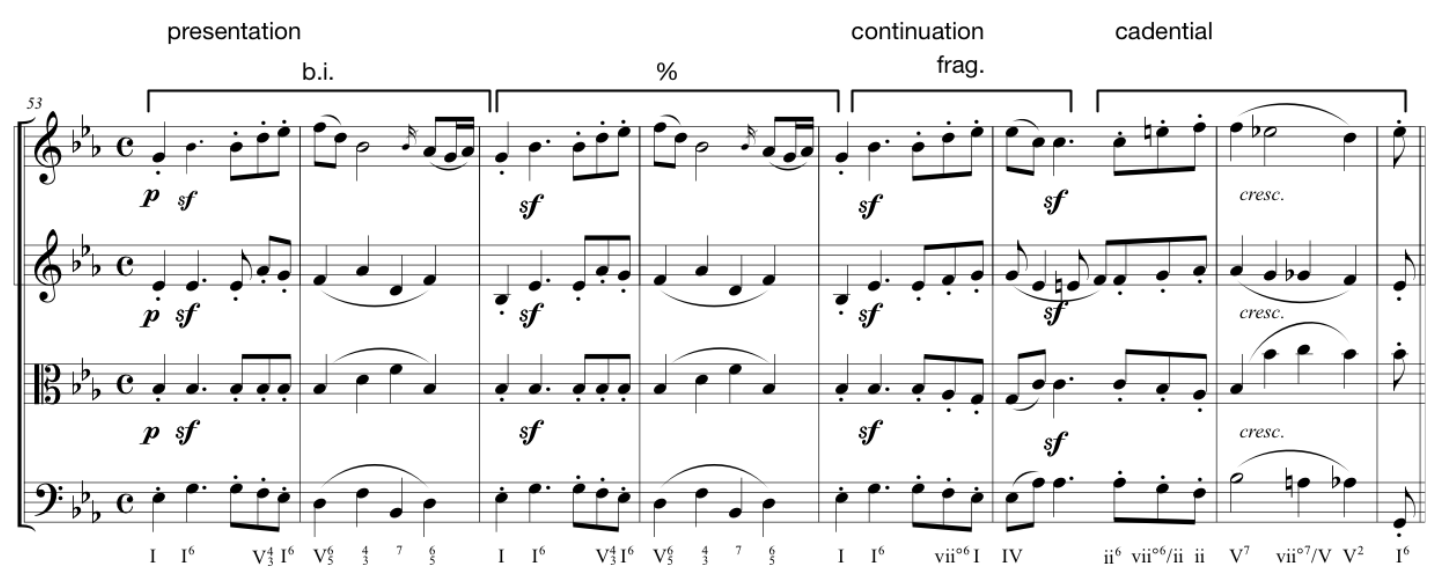

Example 6: Beethoven, String Quartet in C Minor, Op. 18 № 4/I, mm. 53-63

A new topic appears in the closing section of the exposition, after a PAC on the subordinate key in measures 69-70, which sets a calmer but darker tone to the music (Example 7). The first impression drawn from this passage is that of a "tiptoe" gesture of the arpeggi and scales before the cadential movements in measures 73 and 77, the first on the subordinate key and the second leading back to the home key. We could read this "tiptoe" gesture as a reference to dramatic universe since we have already been confronted with buffa style topics in the movement; however, the correlation between the gesture and a comic one occurs when the "tiptoe" is tropified with a march topic, creating a comic scene ${ }^{13}$. The

13 See Hunter, Topics and Opera Buffa, p. 74-75.

\section{MUSICA THEORICA}


buffa-style is still lurking, albeit the lack of a march, behind the main dominant topic of the passage: the ombra. The passage carries several characteristics of the topic, conforming with McClelland's description ${ }^{14}$, such as a dark and ominous tone, slow tempo, and surprise effects that play with audience's expectations. The keys of Eb major and $\mathrm{C}$ minor are prototypical of the topic, and its relation to the tempesta (as McClelland ${ }^{15}$ would describe, "different sides of the same coin") justifies Beethoven's choice to write an ombra before the return to the main theme, as if it were a preparation for the change of tone between main and subordinate themes.

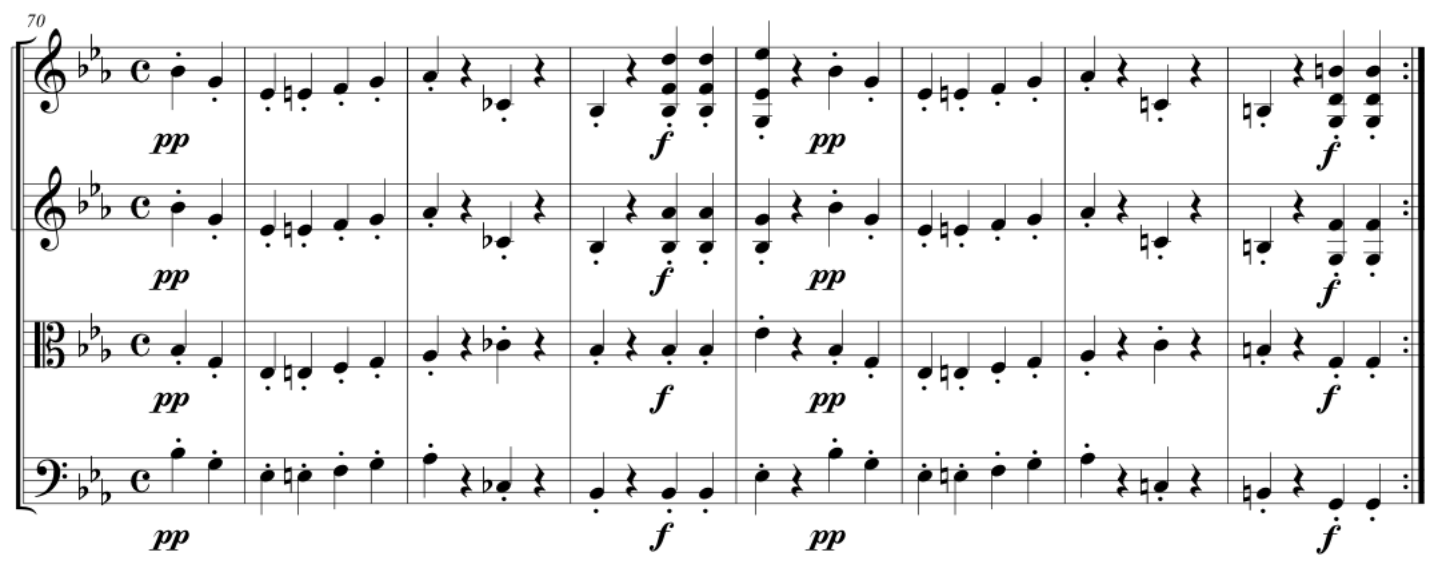

Example 7: Beethoven, String Quartet in C Minor, Op. 18 № 4/I, mm. 70-77.

When the closing section is leading to the development, after the repetition of the movement's first part, the second "surprise" dominant chord is rewritten in the key of G minor, connecting with the opening of a development which is mainly a modified restatement of the exposition ${ }^{16}$. The whole development is organized as follows: first we hear a main theme-like passage in G minor ( $\mathrm{mm}$. 78-90) which restates the main theme without the tonic pedal; a transition-like segment follows (mm. 90-111) with fragmentations of the main theme and imitative passages culminating in the repeated PAC gesture from the transition, trailing along the sequence of keys $\mathrm{G}$ minor $\Rightarrow \mathrm{C}$ minor $\Rightarrow \mathrm{F}$ minor; after a half cadence in the dominant of $\mathrm{F}$ minor a subordinate theme-like passage (mm. 111128) based on the first of the two subordinate themes starts in F major and is then restated in F minor; lastly, the subordinate theme-like passage ends with the arrival of a standing on the dominant in the home key (mm. 128-135). The topical

\footnotetext{
14 See McClelland, Ombra and Tempesta, p. 282, figure 10-1.

15 Ibid., p. 285.

16 Ratner, Classical Music, p. 228.
} 
content of this section is almost the same of the exposition with main differences in the transition and standing on the dominant. Tempesta is the main dominant topic in the transition-like passage; however, Beethoven uses the learned style (with a use of strict counterpoint) to connect the keys of $\mathrm{G}$ minor and $\mathrm{C}$ minor (Example 8) and C minor and F major (Example 9). Since the tempesta topic that precedes both passages is mainly related to a forward-driving rhythm, the learned style passages in mm. 94 and 102 break and stall the rhythm for a short period of time and then start gaining momentum for the return of the tempesta. The standing on the dominant has a similar topic function as the closing section, a preparing ombra, here in a more supernatural clothing and without the element of surprise, with its stall harmony and tremolos working as a stable force upon which other elements-such as the first violin and cello lines-work as disruptive (Example 10).

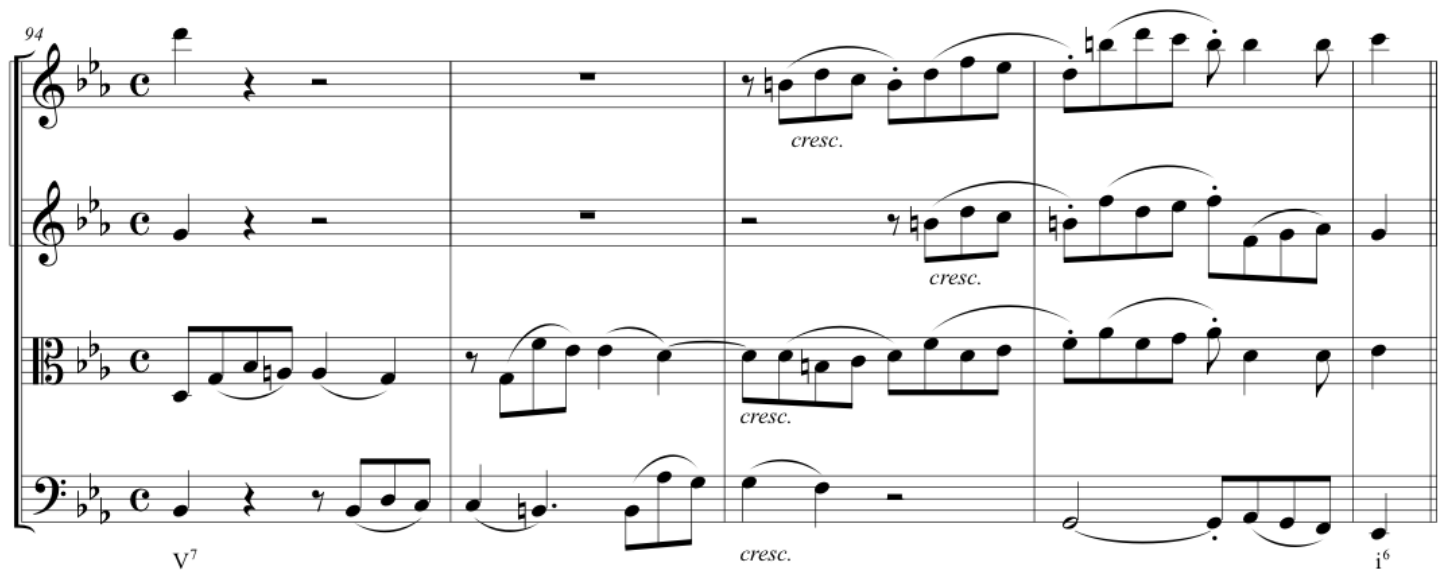

Example 8: Beethoven, String Quartet in C Minor, Op. 18 № 4/I, mm. 94-98.

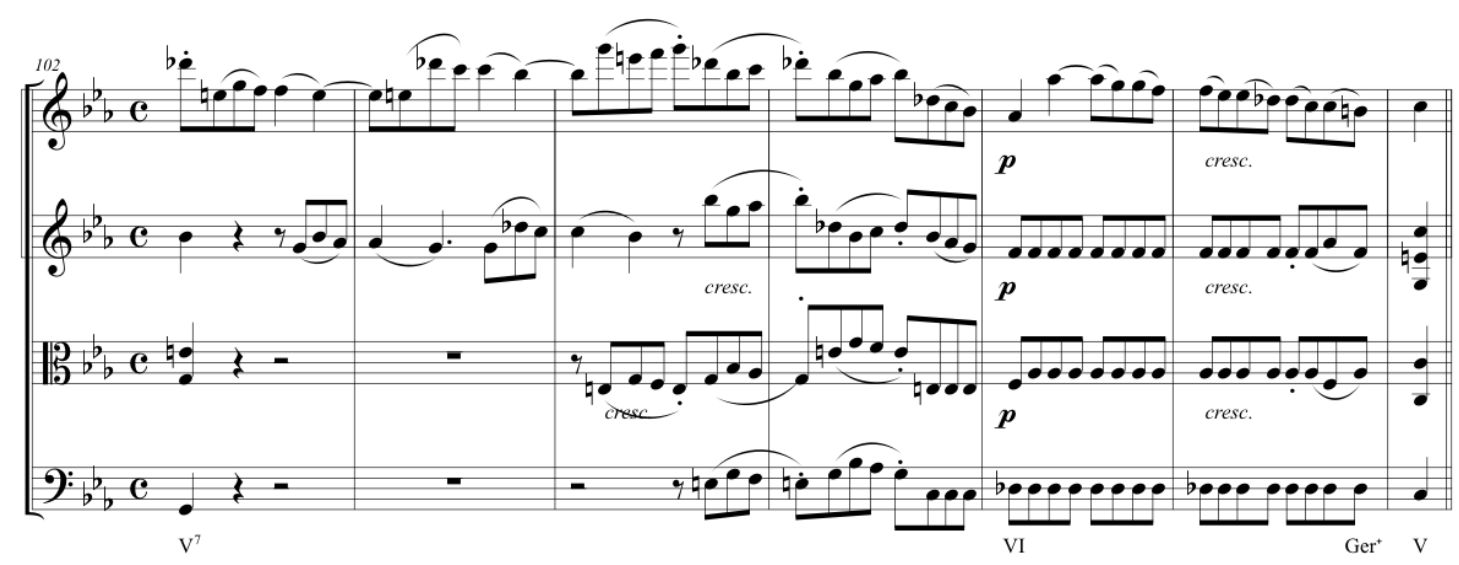

Example 9: Beethoven, String Quartet in C Minor, Op. 18 № 4/I, mm. 102-108. 


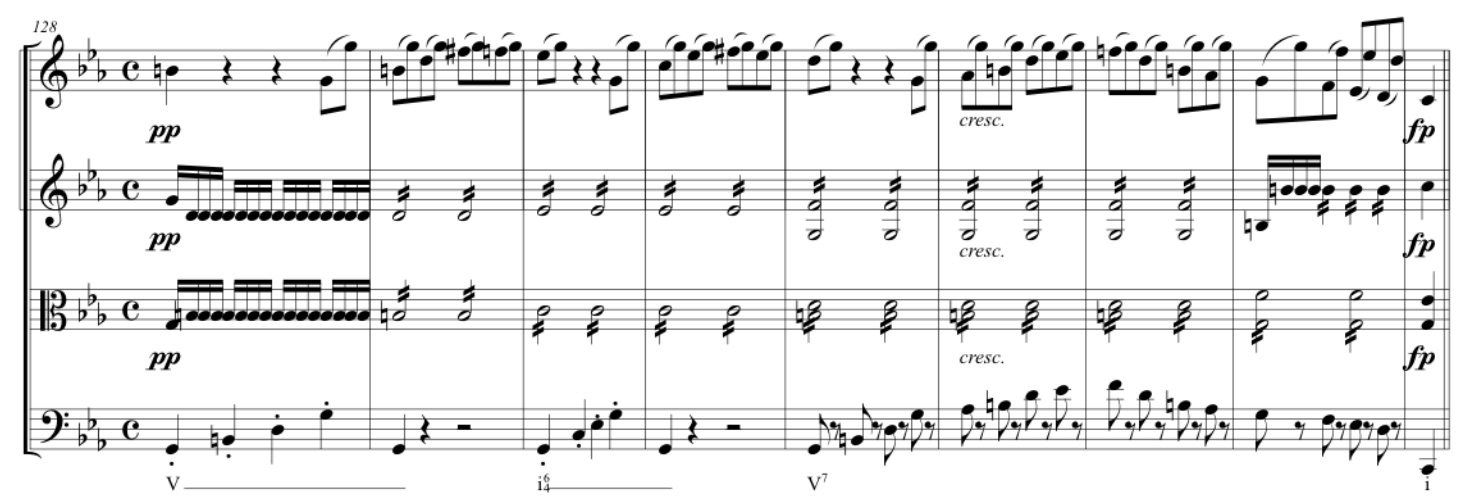

Example 10: Beethoven, String Quartet in C Minor, Op. 18 № 4/I, mm. 128-136.

Regarding the development, it is interesting to point out three main aspects concerning topics. First, that the passage maintains the overall dominance of the tempesta topic, even with the established opposition between tragic and comic in the exposition. Second, that such opposition is hinted in the subordinate theme-like passage with the major-then-minor presentation of the first subordinate theme. This opposition-as Hatten observes ${ }^{17}-$ is viewed as unmarked (non tragic, major) and marked (tragic, minor) relation in the Classical style: here the unmarked and less specific major mode refers to comic (buffastyle) and lyric expressions (singing style). Third, that the ombra topic is strategically used as a way of transitioning back from the unmarked to the marked elements in this asymmetrical opposition.

Normally, the classical place for settling unresolved contrasts and oppositions of the sonata form is in its recapitulation. From a formal perspective, the movement's contrasting tonal fields opposition is solved with a subordinate theme group transposed to C major (mm. 157-194). The subordinate theme comes after a non-modulating transition which stretches itself to farther harmonic regions (such as bII and iii) and omits the buffa-like second part heard in the exposition (Example 11). This view is, nevertheless, insufficient here: the idea of contrasting tonal field is weaker in most minor-mode sonatas, since home and subordinate keys share the same basic scale ${ }^{18}$; the exposition's opposing (and most prevalent) topics are not resolved in the recapitulation considering the omission of the commenting operatic gestures from the transition; and lastly, the second opposition between marked and unmarked tonal regions exposed in the development is yet to be resolved.

\footnotetext{
${ }_{17}$ Musical Meaning in Beethoven, p. 36.

18 Caplin, Classical Form,p. 195.
} 


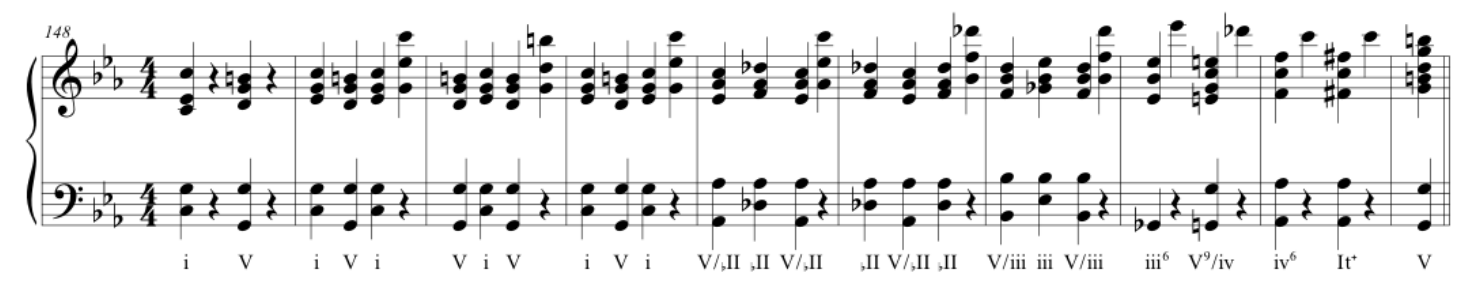

Example 10: Beethoven, String Quartet in C Minor, Op. 18 № 4/I, mm. 148-157 (piano reduction)

Last, is in the coda where Beethoven solves all these contrasts. In only a few measures after the start of the coda, right after a PAC on C minor in $\mathrm{m}$. 208, the omitted buffa style theme of the transition is presented with a tempesta topic. The opposition proposed in the exposition is therefore resolved by means of dominating the buffa or comic style with the terror of the more dominant topic, the tempesta. Harmonically, the section has a few differences but the double presentation of a Fenaroli schema is still present: the first in $\mathrm{C}$ minor and the second in F minor (Example 12), this time with the prototypical (0-(1)-2-3 melody over the bass which connects with a cadence in $\mathrm{C}$ minor. Therefore, all the markers that led to the interpretation of a buffa style topic in $\mathrm{mm}$. 26-33 are incorporated (or dominate) by the tempesta topic, which further dissolves these markers yielding power to the strong, tempestuous ending over a tonic pedal (mm. 204-209). 


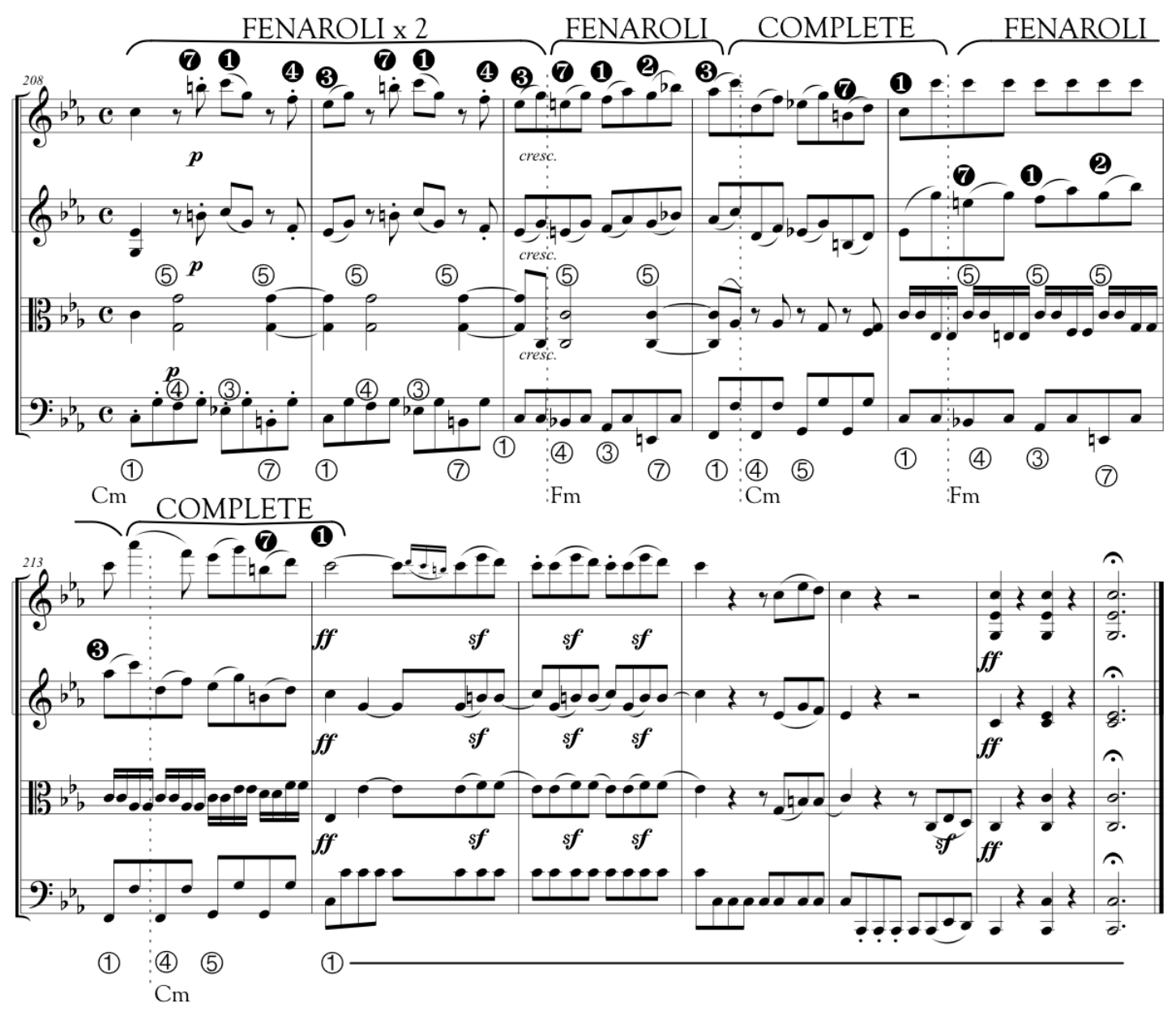

Example 12: Beethoven, String Quartet in C Minor, Op. 18 № 4/I, mm. 208-219.

\section{4 - Final Considerations}

I attempted here in this concise analysis to confront some of the most influential theories of modern musicology by means of discussing their relative impact on the interpretation of a singular work. I will discuss here three main considerations points drawn from the analysis regarding these theories: (1) topics and formal functions; (2) topics and harmonic schemata; (3) productivity aspects of tropes encountered in the piece.

(1) I share Caplin's insight ${ }^{19}$ that the choice of topics in formal functions does not follow a set of rules but rather a higher or lower inclination of certain topics to appear in certain formal functions. We demonstrated in the analysis herein that some topics such as ombra could be used as transitional functions

${ }_{19}$ On the relation of Musical Topoi, p. 124. 
when connecting non-tragic and tragic elements. This is possible mainly because of the close relation between the two topics, which is also present in Opera Buffa (another referenced universe in the quartet), as illustrated in Example 13. In one of Uberto's arias from Pergolesi's La Serva Padrona (1733), he expresses mixed feelings (Soi imborgliato io già) about his servant Serpina after she announces her intent to marry a military man (Tempesta). The whole aria has a general stormy character that correlates with tempesta topic, despite its less usual tonal region $(\mathrm{Eb})$ and thin texture. At some point in the middle of the aria, after questioning the character of his feelings, Uberto announces that he hears a voice that warns him to ponder his decisions (Sento un che, poi mi dice: Uberto, pensa a te). Pergolesi sets this voice in an ombra passage ( $\mathrm{mm} .65-74)$, raising a possible interpretation of a supernatural voice of conscience talking to Uberto - that rapidly storms again in contrasted frenzy feelings (mm.74-82).
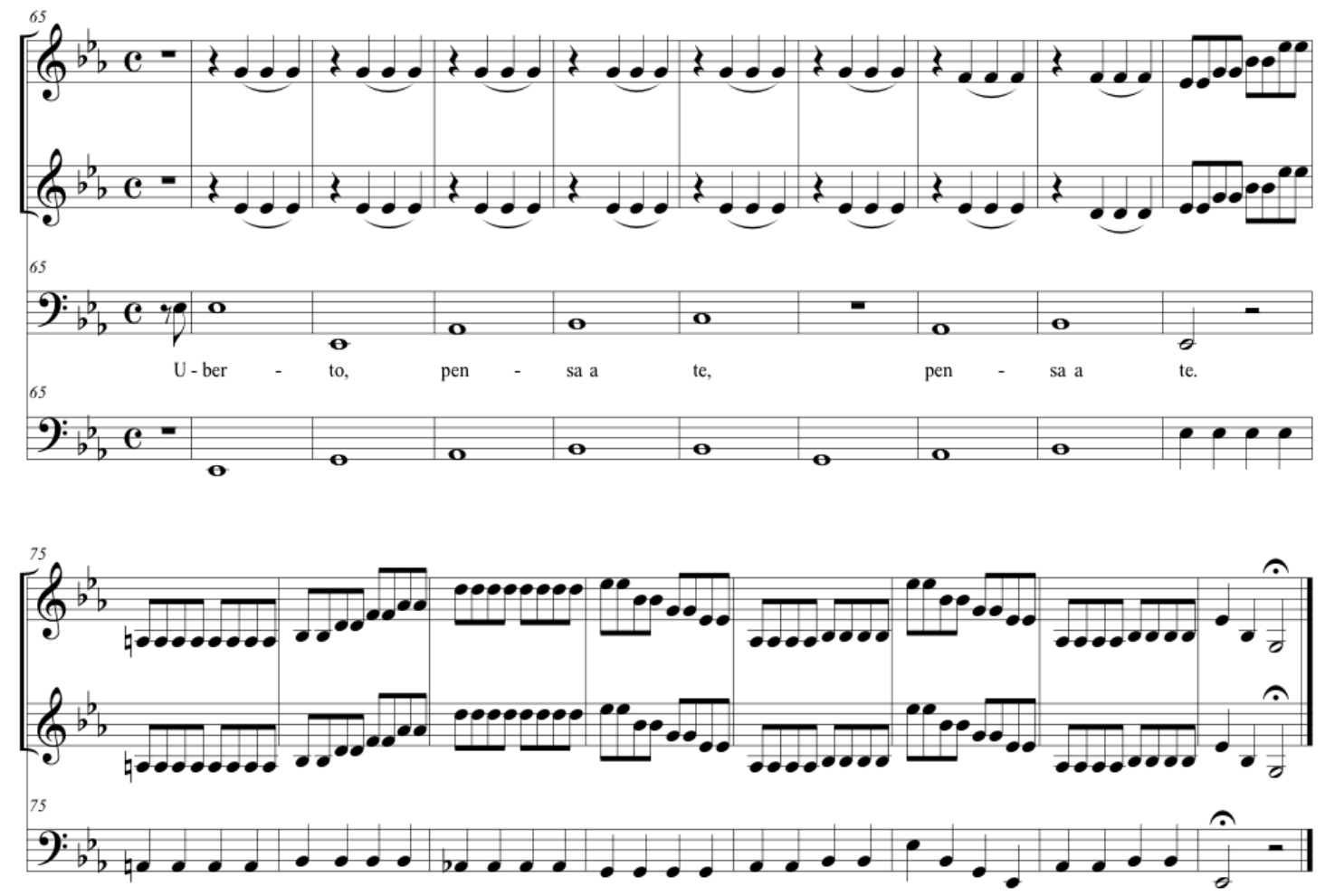

Example 13: Ombra and tempesta topics in Son imbrogliato io già from Giovanni Battista Pergolesi's La Serva Padrona, mm. 65-82.

(2) Analogous to the relation of topics and formal functions is the relation between topics and harmonic schemata. They both seem to be closely related to a possibility, or a lack of, syntax in topic theory, which is clearer when it comes to the relation with musical schemata. Galant schemata are mainly syntactical elements of music, whereas topics are semantical ones. It is possible for a galant 
schema to gain a certain semantical connotation and carry its semantical values forming a syntax-lexicon continuum such as the Stabat Mater Prinner and the learned style ${ }^{20}$. In our analysis of the first movement of Op. 18, we found no such relation; however, the use of galant schemata was fundamental for the description of the buffa style topic, serving as a marker, which would later be used to reconfigure the topic and assert the tempesta dominance.

(3) Lastly, I believe the degree of productivity in the "tropological encounters" of the movement circles around four main topics: tempesta, buffa style, singing style, and bourrée. Many of these topics are blended together throughout the discourse, but the main contrast comes from the tempesta/buffa opposition, if we imagine the buffa style here as a reference of comic character. Therefore, this specific trope-although not highlighted in the development section-is resolved in the coda section, thus evolving "as a culminating, integrative means of achieving thematic and expressive closure among competing themes and their individual topical characters" ${ }^{21}$.

\section{References}

1. Allanbrook, Wye J. 1983. Rhythmic Gesture in Mozart: Le nozze di Figaro and Don Giovanni. Chicago: University of Chicago Press.

2. 2014. Secular Commedia: Comic Mimesis in Late EighteenthCentury Music. Edited by Mary Ann Smart and Richard Taruskin. Berkeley: University of California Press.

3. Byros, Vasili. 2014. Topics and Harmonic Schemata: A Case from Beethoven. In: The Oxford Handbook of Topic Theory, p. 381-414. Danuta Mirka (ed.). Oxford: Oxford University Press.

4. Caplin, William E. 1998. Classical Form: A Theory of Formal Functions for the Instrumental Music of Haydn, Mozart, and Beethoven. New York: Oxford University Press.

5. 2005. On the Relation of Musical Topoi to Formal Function. Eighteenth-Century Music vol. 2, no. 1, p. 113-124.

\footnotetext{
20 See Byros, "Topics and Harmonic Schemata" and Roman Ivanovitch "Mozart's Art of Retransition". Music Analysis, vol. 30, no. 1, 2011, p. 1-36.

${ }^{21}$ Hatten, The Troping of Topics, p. 525.
} 
6. Cobley, Paul. 2008. Communication and verisimilitude in the eighteenth century. In: Communication in Eighteenth-Century Music, p. 14-33. Danuta Mirka and Kofi Agawu (eds.). Cambridge: Cambridge University Press.

7. Day-O'Connel, Sarah. 2014. The Singing Style. In: The Oxford Handbook of Topic Theory, p. 238-259. Danuta Mirka (ed.). Oxford: Oxford University Press.

8. Gjerdingen, Robert O. 2007. Music in the Galant Style. New York: Oxford University Press.

9. Hatten, Robert S. 1994. Musical Meaning in Beethoven: Markedness, Correlation, and Interpretation. Bloomington: Indiana University Press.

10. 2014. The Troping of Topics in Mozart's Instrumental Works.

In: The Oxford Handbook of Topic Theory, p. 514-539.Danuta Mirka (ed.). Oxford: Oxford University Press.

11. Hepokosky, James; Warren, Darcy. 2006. Elements of Sonata Theory: Norms, Types, and Deformations in the Late-Eighteenth-Century Sonata. New York: Oxford University Press.

12. Hunter, Mary. 2014. Topics and Opera Buffa. In: The Oxford Handbook of Topic Theory, p. 61-90. Danuta Mirka (ed.). Oxford: Oxford University Press.

13. Ivanovitch, Roman. 2011. Mozart's Art of Retransition. Music Analysis, vol. 30, no. 1, p. 1-36.

14. Kallberg, Jeffrey. 1996. Chopin at the Boundaries: Sex, History, and Musical Genre. Cambridge: Harvard University Press.

15. Little, Meredith E. 1975. The Contribution of Dance Steps to Musical Analysis and Performance: 'La Bourgogne'. Journal of the American Musicological Society, vol. 28, no. 1, p. 112-124.

16. McClelland, Clive. 2014. Ombra and Tempesta. In: The Oxford Handbook of Topic Theory, p. 279-300. Danuta Mirka (ed.). Oxford: Oxford University Press.

17. Mirka, Danuta. 2008. Introduction. In: Communication in Eighteenth-Century Music, p. 1-10. Danuta Mirka and Kofi Agawu (eds.). Cambridge: Cambridge University Press.

18. Ratner, Leonard G. 1985. Classic Music: Expression, Form and Style. New York: Schirmer Books. 